DOI: https://doi.org/10.15407/kvt204.02.084

UDC 615.47: 004.9

VOVK M.I., PhD (Biology), Senior Researcher,

Head of the Bioelectrical Control

\& Medical Cybernetics Department

ORCID: 0000-0003-4584-9553

e-mail: vovk@irtc.org.ua; imvovk3940@gmail.com

KUTSIAK O.A., PhD (Engineering),

Senior Researcher of the Bioelectrical Control

\& Medical Cybernetics Department

ORCID: 0000-0003-2277-7411

e-mail: spirotech85@ukr.net

International Research and Training Center for Information Technologies

and Systems of the NAS of Ukraine and of MES of Ukraine, 40, Acad. Hlushkov av. Kyiv, 03187, Ukraine

\title{
Al-TECHNOLOGY OF MOTOR FUNCTIONS DIAGNOSTICS AFTER A STROKE
}

Introduction. Diagnostics of motor functions plays an important role in the motor functions restoration after stroke. Synthesis of effective technologies for personalized assessment of motor functions disorders at different rehabilitation stages is an urgent scientific and applied task.

The purpose of the paper is to develop information technology for diagnostics of motor functions deficit after stroke, that uses artificial intelligence tools to increase the effectiveness of the diagnostic process.

Results. The theoretical and practical foundations to synthesize AI-technology for personal diagnostics of motor functions deficit, and the assessment of their restoration as a result of rehabilitation measures after stroke have been developed. For informational assistance to the physician in the diagnostic process, artificial intelligence is used. A new class of mobile digital medicine tools - the specialized software modules for motor functions diagnostics "MovementTestStroke 1.1 (PC)" installed in the PC-structure, and "MovementTestStroke 1.1 (MD)" installed in mobile platforms running under Android operation system have been developed. Software implementation - Visual Studio 2019, C\# programming language. Structural and functional models of user - software modules interaction, algorithms for motor function deficit diagnostics, and UML-diagrams of these modules are presented.

Functional features of the technology: an expanded range of evidence criteria for personalized quantitative assessment of limb movements deficit, storage in the Database and display on the interface the results of deficit assessment, as well as the deficit dynamics during the rehabilitation course in a convenient form (tables, graphs) make it possible to reduce the physician's error, prevent complications, identify the disorders specifics, compare the rehabilitation effectiveness of the upper and lower limbs, their distal and proximal parts, including fine motor skills of the hand, restoration of which helps to restore speech in motor or motor and sensory aphasia.

Conclusions. The usage of artificial intelligence tools to diagnose motor deficit will increase the diagnostic effectiveness, and, as a consequence, rehabilitation services for patients after stroke.

Keywords: diagnostics, motor functions, stroke, personal quantitative assessment, criteria, technology, artificial intelligence, software module, structural-functional model, algorithm, activity diagram.

(c) VOVK M.I., KUTSIAK O.A., 2021 


\section{INTRODUCTION}

For many years, stroke is one of the main causes of disability and death both in the world and in Ukraine. Of particular concern is the increasing burden of stroke among people of working age: more than $50 \%$ of stroke survivors never return to work. In Europe an action plan to combat stroke in 2018-2030 is approved [1]. One of the main consequences of stroke is motor activity disorders: paralysis, paresis, problems with coordination, muscle hypertone, loss of sensitivity in the arms and legs, etc. A significant place is also occupied by speech disorders, among which the most common is motor aphasia due to affection of the motor speech zone of the cerebral cortex, where the speech motor program is formed. Muscular movements of speech apparatus are one type of voluntary muscular movements. The synthesis of effective methods, techniques and technologies of personalized voluntary movements restoration is an actual scientific and applied task.

\section{PROBLEM STATEMENT}

The complete motor functions rehabilitation is associated with the adequate mobilizing of the patient's reserves on restoration of affected or lost functions according to his state. Therefore, the movements deficit diagnostics after stroke at each rehabilitation stage plays an important role, especially with methods and tools of digital medicine, which provides of quantitative assessment of disorders depth.

As a result of previous studies, a new technique for quantitative assessment of motor functions deficit after stroke has been developed. This technique was based on main and additional expert evidence criteria [2], and has passed prior clinical approbation during researches of movements restoration dynamics after stroke by new technology TRENAR ${ }^{\circledR}$ for training / restoring the motor functions [3]. The test results confirmed the technique advantages and feasibility of its using in clinical practice [2].

Recently, more and more attention is paid to attempts to apply artificial intelligence (AI) technologies in medicine $[4,5]$. "AI is poised to play an increasingly prominent role in medicine and healthcare because of advances in computing power, learning algorithms and the availability of large datasets (big data) sourced from medical records and wearable health monitors" [6]. It is considered that "artificial intelligence in a smartphone will make available the medicine of future to everyone: any mobile phone user will have a personal medical assistant, capable in real time mode to solve problems related to specific person's health. ... And it is not yet known, when artificial intelligence will be good enough to make $100 \%$ accurate recommendations to physicians about the best treatment. However, AI is already able to make medical personnel work much easier, improve the diagnostics accuracy and help patients in solving everyday tasks." [7].

As for the movements deficit diagnostics after stroke, this new approach provides of using the specialized software modules as "virtual assistants" to physician in making diagnostic decisions in the diagnostic process.

The implementation of AI tools, in particular for personalization and expanding the functionality of diagnostic process, reducing the expert's error and identifying the stroke disorders specifics, personalization of the preventive and rehabilitation measures, will increase the effectiveness and mass usage of the rehabilitation services for patients after stroke, will improve the quality of these services. In combination with telemedicine services such technologies will expand access for patients to qualitative medicine. 
The purpose of the paper is to develop information technology for diagnostics of motor functions deficit after stroke, that uses artificial intelligence tools to increase the effectiveness of the diagnostic process.

\section{INFORMATION ASSISTANCE FOR PERSONALIZED MOTOR FUNCTIONS DIAGNOSTICS BASED ON THE USE OF ARTIFICIAL INTELLIGENCE TOOLS}

The process of personalized motor functions diagnostics based on the use of artificial intelligence tools - specialized software modules of information assistance to the physician in diagnosing limbs movements after stroke "MovementTestStroke 1.1 (PC)" for personal computer, and "MovementTestStroke 1.1 (MD)" for mobile devices are presented and described by appropriate structural and functional models (Fig. 1, Fig. 2).

Structural and functional model of user - software module interaction for quantitative assessment of motor functions in patient "MovementTestStroke 1.1 $(P C)$ » in the structure of personal computer is shown on Fig. 1. This software module consists of the graphical user interface (GUI) and the module's objects main information units: I - Database, II - Information unit for quantitative assessment of motor functions deficit (hereinafter - Assessment unit).

These units are connected with GUI that provides for user a dialog operation mode with them:

- inputting the patient's express information to Database through the GUI, calling the patient's motor functions deficit assessment information during the current course or for previous rehabilitation courses (1);

- creating the access to patient's personal electronic medical record (EMR) in Database, sending the request to display of dynamics of patient's motor functions deficit assessment during the current course or for previous rehabilitation courses to Database (2);

- selecting the motor functions tested object (limb, hand, form of walking) through the GUI, inputting the quantitative indicators of motor functions deficit by evidence criteria in points in relevant tables of tested object (3);

- displaying the scales of motor functions expert assessment by user (physician) according to tested object by main and additional evidence criteria, and determination of quantitative indicators of motor functions deficit in points on their basis (4);

- storing the current results of distributed expert and integrated quantitative assessment of motor functions in points in Database (5);

- loading the data of integral quantitative assessment of motor functions in points of the first test to assess the motor functions restoration effectiveness (6);

- sending the results of current distributed expert and integrated quantitative assessment of motor functions for forming their imaging in tabular form (7);

- outputting the general results of the distributed expert and integrated quantitative assessment of motor functions in tabular form to user (physician) through the GUI (8);

- loading the data on dynamics of motor functions deficit assessment in points during the current course or for previous rehabilitation courses (9);

- outputting the dynamics of patient's motor functions deficit assessment during the current course or for previous rehabilitation courses through the GUI in tabular and graphical forms (10). 


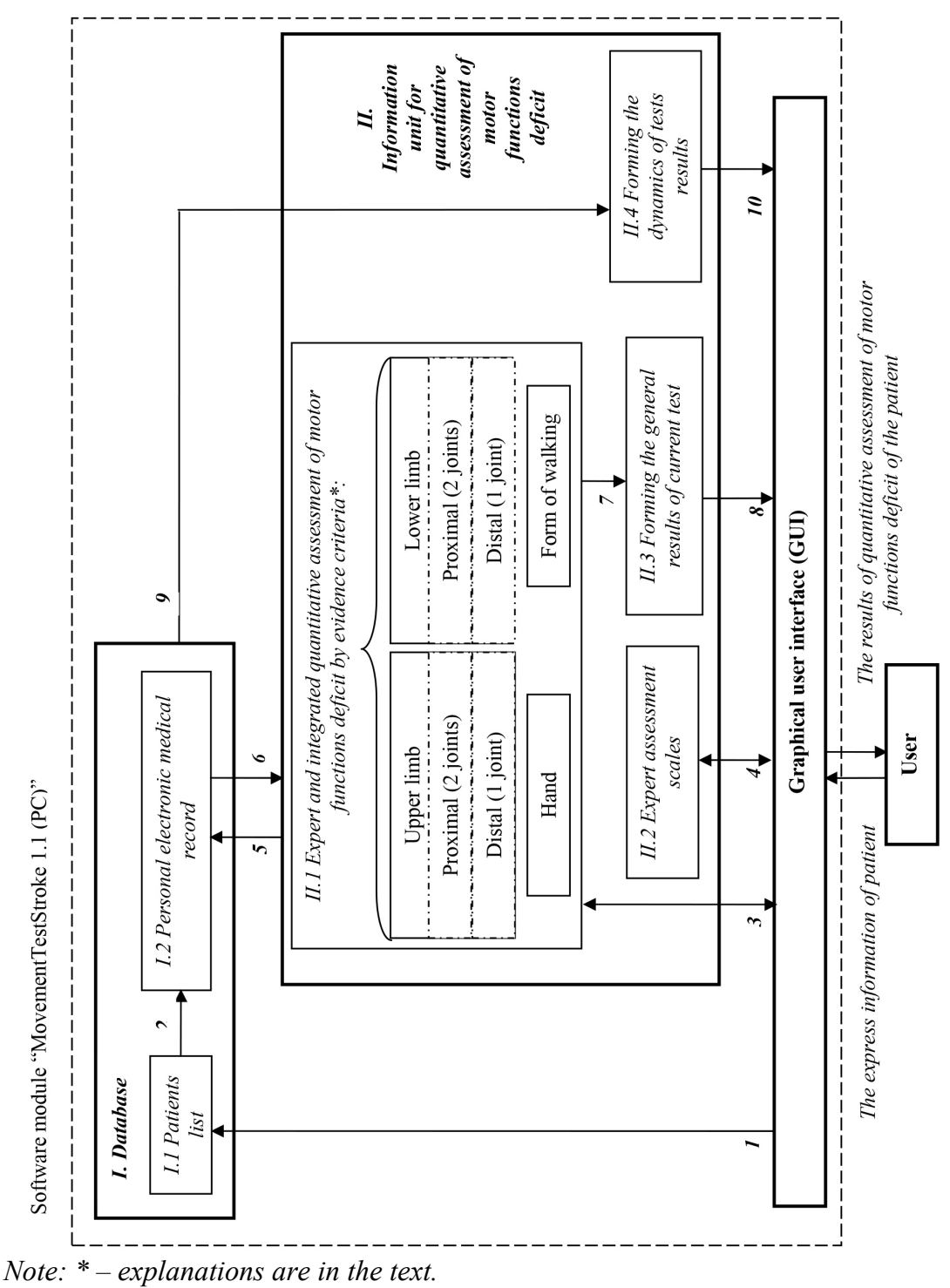

Fig. 1. Structural and functional model of user - software module interaction for quantitative assessment of motor functions in patient "MovementTestStroke 1.1 (PC)" (marking descriptions are in the text)

Information unit $I$ "Database" is designed for storing the information on each patient who has already passed or patient's limbs motor functions are tested for the first time, and consists of two components: I.1 "List of patients" and I.2 "Personal electronic medical record".

The component $I .1$ is formed in tabular list form, in which each patient is shown by express information record (hospitalization date, patient's surnameinitials-sex, medical card number, physician's name) according to the standard (form 003/o "Medical card of patient"). According to object-oriented programming (OOP) methods, the user checks (1) the presence of right patient through the GUI, and if patient is absent, user adds (1) to Database patient's express 
information from the medical card. The presence of the patient in the list makes it possible to create (2) access to personal EMR in Database.

In component $I .2$ of Database the results of distributed expert and integrated quantitative assessment of motor functions deficits according to evidentiary criteria throughout the course of patient rehabilitation are stored.

The purpose of Information unit II - Assessment unit is for inputting (3) the expert assessment data of motor functions deficit in points by evidence criteria according to evaluation scales by user (physician) through the GUI, quantitative assessment of movements deficit, outputting (8) the general results of distributed and integrated quantitative assessment, and their dynamics (10) during patient's rehabilitation course through the GUI.

According to the purpose this unit consists of components: II.1 "Distributed expert and integrated quantitative assessment of motor functions deficit by evidence criteria", II.2 "Expert assessment scales", II.3 "Formation of generalized results of current test", II.4 "Forming the dynamics of test results".

In component II. 1 of motor functions Assessment unit, the user carries out distributed expert assessment based on appropriate scales of the Protocol for quantitative assessment of movements deficit of patient after stroke [8]:

- by main evidence criteria (muscle strength, movement's volume) [9] of movements deficit of upper and lower limbs at the individual joint level in proximal (2 joints) and distal (1 joint) parts;

- by additional evidence criteria of fine motor skills of the hand (contrasting the thumb, flexing the hand's fingers in fist, the hand's main motor function (capturing), the hand's fingers extension) and form of walking [8, 10];

- of muscle hyper- or hypotone [8, 9].

And also integrated quantitative assessments at the individual joint level of specified parts of upper and lower limbs or hand are calculated by the program.

It is the implementation of additional evidence criterion for hand's fingers extension that "MovementTestStroke 1.1 (PC)" differs from the previously developed "MovementTestStroke 1.0 (PC)" [8, 11].

The functional purpose of component II.1 is the separate presentation of motor functions tested objects (limb, hand, form of walking) and their evidence criteria in tabular form. Motor functions deficit at the individual joint level of proximal and distal parts of upper and lower limbs, fine motor skills of the hand and form of walking can be assessed by choice. The user through the GUI selects (3) tested object, calls expert assessment scales by evidence criteria according to tested object on the GUI (4), determines the quantitative indicators of the motor functions deficit in points, and inputs them (3) in appropriate tables of tested object.

Then the program calculates the integrated assessments of motor deficit by amount of evidence criteria: for the limbs - by two criteria, for fine motor skills of the hand - by four criteria, and determines the paresis degree (plegia, severe paresis, major paresis, moderate paresis, mild paresis, disorders absence).

If patient's motor functions test is performed not for the first time in rehabilitation course, the component II.1 receives (6) integrated assessments data of motor functions deficit of the first test from component $I .2$ of Database. The motor functions restoration effectiveness is calculated by comparing the integrated assessments for current and first tests in component II.1. 
The current test results of motor functions in points and motor functions restoration effectiveness are stored (5) in component I.2 of Database.

From component II.1 the results of distributed expert and integrated quantitative assessment of motor functions deficit by evidence criteria of patient current test are sent (7) to the component II.3, and are output (8) in tabular form to user through the GUI.

Data of distributed expert and integrated quantitative assessment of patient's motor functions deficit for current and previous tests in current rehabilitation course are received (9) from component I.2 of Database to component II.4 of Assessment unit to form the dynamics of both expert and integrated quantitative assessment of motor functions deficit, and are output to user through the GUI (10) in tabular and graphical form.

In addition the dynamics of patient's motor functions deficit during the current or for previous rehabilitation course can be viewed by user without testing. To do this in the Database the request (1) to component $I .1$ is transmitted (2) to component I.2, and the appropriate motor functions test data are transmitted (9) to component II.4 of Assessment unit. The generated dynamics is output (10) to user through the GUI in tabular and graphical form.

Structural and functional model of user - software module interaction for quantitative assessment of motor functions in patient "MovementTestStroke 1.1 (MD)" on mobile devices is shown on Fig. 2. This software module consists of the GUI and module's objects - the main information units: $\boldsymbol{I}$ - Database, $\boldsymbol{I}$ - Information unit for quantitative assessment of motor functions deficit (or Assessment unit).

These units are connected with GUI that provides for user a dialog operation mode with them:

- inputting the patient's express information to Database through the GUI (1);

- creating the access to patient's personal electronic medical record (EMR) in Database (2);

- selecting the motor functions tested object (limb, hand, form of walking) through the GUI with evidence criteria for its assessment, and then selecting the right verbal characteristic on the assessment scale by selected evidence criterion, outputting the quantitative indicator of motor functions deficit in points by selected evidence criterion through the GUI (3);

- program calling the motor functions deficit assessment scale by evidence criterion according to the tested object (4);

- sending the results of current test's results of distributed expert assessment of motor functions to calculate the integrated assessments and forming their imaging in tabular form (5);

- outputting the general results of distributed expert and integrated quantitative assessment of motor functions, and motor functions restoration effectiveness to user (physician) through the GUI (6);

- loading the data of integrated quantitative assessment in points of the first test to assess the motor functions restoration effectiveness (7);

- storing the current results of distributed expert and integrated quantitative assessment of motor functions in points in Database (8).

The purpose and structure of Information unit I "Database" corresponds to Database in the structure of personal computer.

As for the Information unit II "Assessment unit" for mobile devices, it should be noted that the purpose of the unit corresponds to similar unit for personal computer, except the function of forming the dynamics of motor functions 
test results (this component is absent). In addition the limitation of the mobile devices screen size causes a difference in relationship between user and information units, their components through the GUI, and also the components functions redistribution of Assessment unit.

These differences are reflected in algorithms for personal computer and mobile devices (appropriately Fig. 4, Fig. 5).

Thus, in component II.1 of Assessment unit the assessment is carried out similarly to component II.1 in personal computer, except the calculation of integrated quantitative assessment of limbs and hand, which is carried out in component II.3.

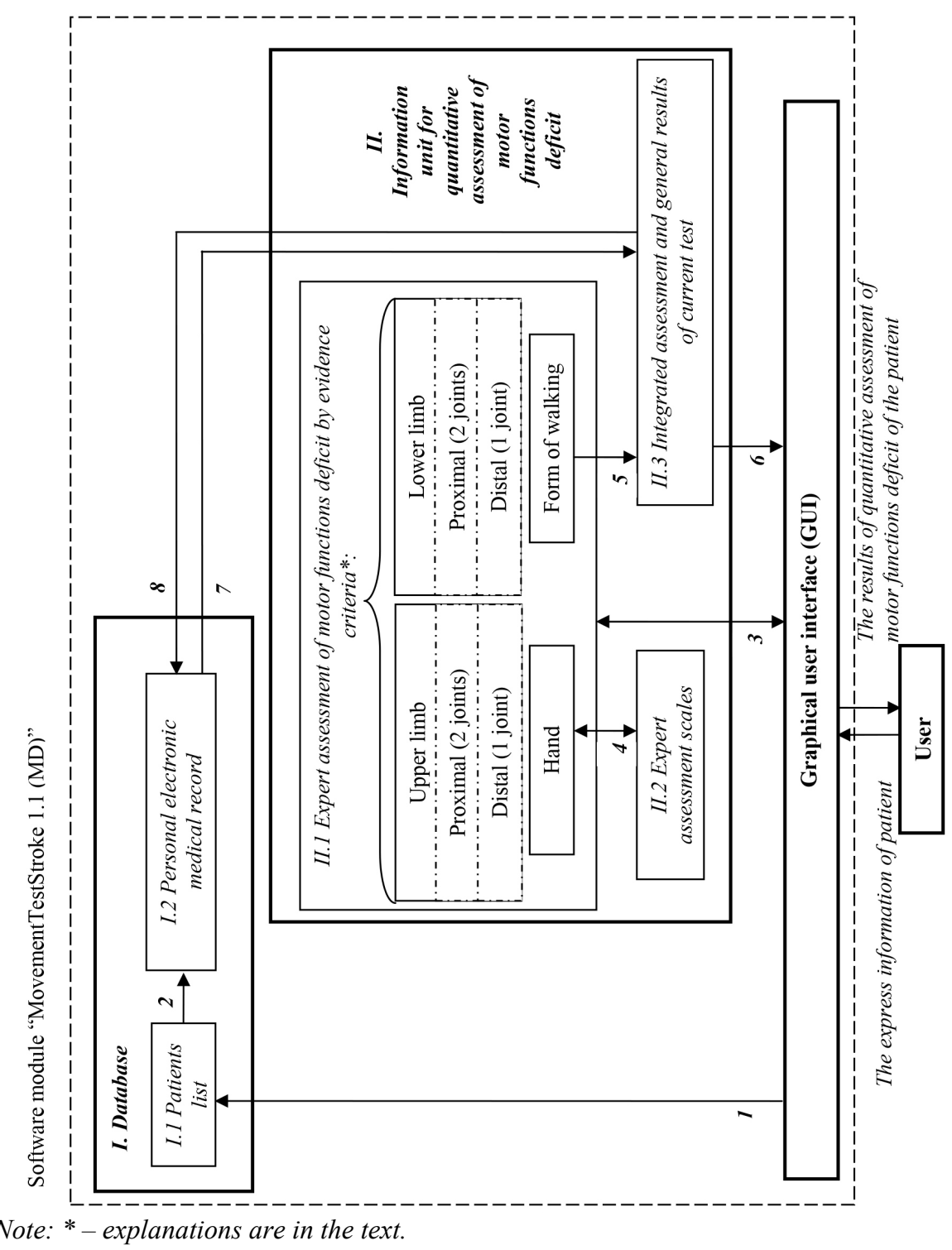

Fig. 2. Structural and functional model of user - software module interaction for quantitative assessment of motor functions in patient "MovementTestStroke 1.1 (MD)" (marking descriptions are in the text) 
As there is no component of dynamics formation in Assessment unit for mobile devices, the calculation of motor functions restoration effectiveness value takes place in component II.3.

The user through the GUI selects (3) the tested object and evidence criteria for its assessment in component II.1. And the appropriate assessment scales by selected evidence criteria according to the tested object are output on the GUI (4). The user selects (3) the right verbal characteristic of criterion through the GUI. By this characteristic the quantitative indicator of motor functions deficit in points is calculated by program and is output on the GUI (3).

Expert assessments of motor functions deficit in points of current test are sent (5) to component II.3, where calculating of the integrated assessments for user-selected tested objects, determination of paresis degree, and output (6) of the general results of distributed expert and integrated quantitative assessment of motor functions deficit of current test through the GUI take place. If the patient's motor functions testing is not performed for the first time in the rehabilitation course, integrated assessments of motor functions deficit of the first test are automatically loaded to component II.3 (7) from component $I .2$ of the Database. The motor functions restoration effectiveness is calculated in component II.3 by comparing the integrated assessments for current and first tests, and also is output (6) to user through the GUI.

The results of distributed expert and integrated quantitative assessment of motor functions deficit for current test, and motor functions restoration effectiveness are stored (8) in component $I .2$ of Database.

The migration to mobile devices compared to personal computer provides for limiting in time the distribution of information presentation on mobile device's screen. According to motor functions tested object, the user through the GUI calls the assessment scale for selected evidence criterion, tests the motor functions and selects on the scale the verbal characteristic value relevant to this criterion. The comparison of indicators for information assistance to the physician in movements deficit assessment for personal computer and mobile devices are presented in Table. 1.

Table 1. The indicators for information assistance to the physician in patient's movements deficit assessment after stroke for personal computer and mobile devices

\begin{tabular}{|c|c|}
\hline Personal computer & Mobile devices \\
\hline \multicolumn{2}{|c|}{ Expert quantitative assessment of movements deficit by evidence criteria in points (from 0 to 5 points) } \\
\hline \multicolumn{2}{|c|}{$\begin{array}{l}\text { Expert quantitative assessment of limb's muscle tone in points (from }-5 \text { to } 0 \text { for hypotone, from } 0 \\
\text { to }+5 \text { for hypertone) }\end{array}$} \\
\hline \multicolumn{2}{|c|}{$\begin{array}{l}\text { Integrated quantitative assessment of movements deficit in points depending on criteria amount (from } 0 \\
\text { to } 10 \text { for limbs, from } 0 \text { to } 20 \text { for fine motor skills of the hand) }\end{array}$} \\
\hline \multicolumn{2}{|c|}{$\begin{array}{l}\text { The paresis degree by integrated quantitative assessment in grades: plegia, severe paresis, major paresis, } \\
\text { moderate paresis, mild paresis, disorders absence. }\end{array}$} \\
\hline $\begin{array}{l}\text { Dynamics of motor functions deficit according to } \\
\text { expert and integrated quantitative assessments in } \\
\text { tabular and graphic forms (both in testing and } \\
\text { through Database). }\end{array}$ & Are absent \\
\hline \multicolumn{2}{|c|}{$\begin{array}{l}\text { Motor restoration effectiveness by comparing integrated quantitative assessments of current and } \\
\text { first motor functions tests in grades: unchanged, minor improvement, improvement, major } \\
\text { improvement. }\end{array}$} \\
\hline
\end{tabular}




\section{ALGORITHMS FOR MOTOR FUNCTIONS TESTING}

According to the structural and functional models (Fig. 1, Fig. 2), the algorithms for motor functions testing by the software modules "MovementTestStroke 1.1" in the structure of personal computer (Fig. 4) and in the structure of mobile devices (Fig. 5) are aimed to quantitative assessment of patient's motor functions deficit.

Movement testing begins with I. Operating with Database (Fig. 3): loading the patients list, checking the presence of the right patient in the list to assess motor functions by user (physician). Operating with Database is the identical part for algorithms for motor functions testing both for PC and mobile platforms.

If the list isn't yet created or such patient is absent, the user inputs express information from patient's medical record for creating / updating the patients list. At the same time the access to patient's personal electronic medical record (EMR) is created. Then the user returns to the updated list.

Then the user moves to operating with Information unit of quantitive assessment of motor functions deficit, where algorithm is separated both for PC and mobile platforms on two parts: II.1 Quantitative assessment of motor functions deficit and II.2 Presentation of the results of quantitative assessment.

In the structure of PC II. 1 the quantitative assessment of motor function deficit begins with selection of tested object of motor functions (limb, hand or form of walking) with the appropriate evidence-based assessment criteria (Fig. 4).

Based on the verbal characteristics, the user determines and fills quantitative indicators of the deficit in the appropriate tables. Based on these indicators in points, calculation of integrated assessment of deficit is performed and paresis degree for tested object is determined.

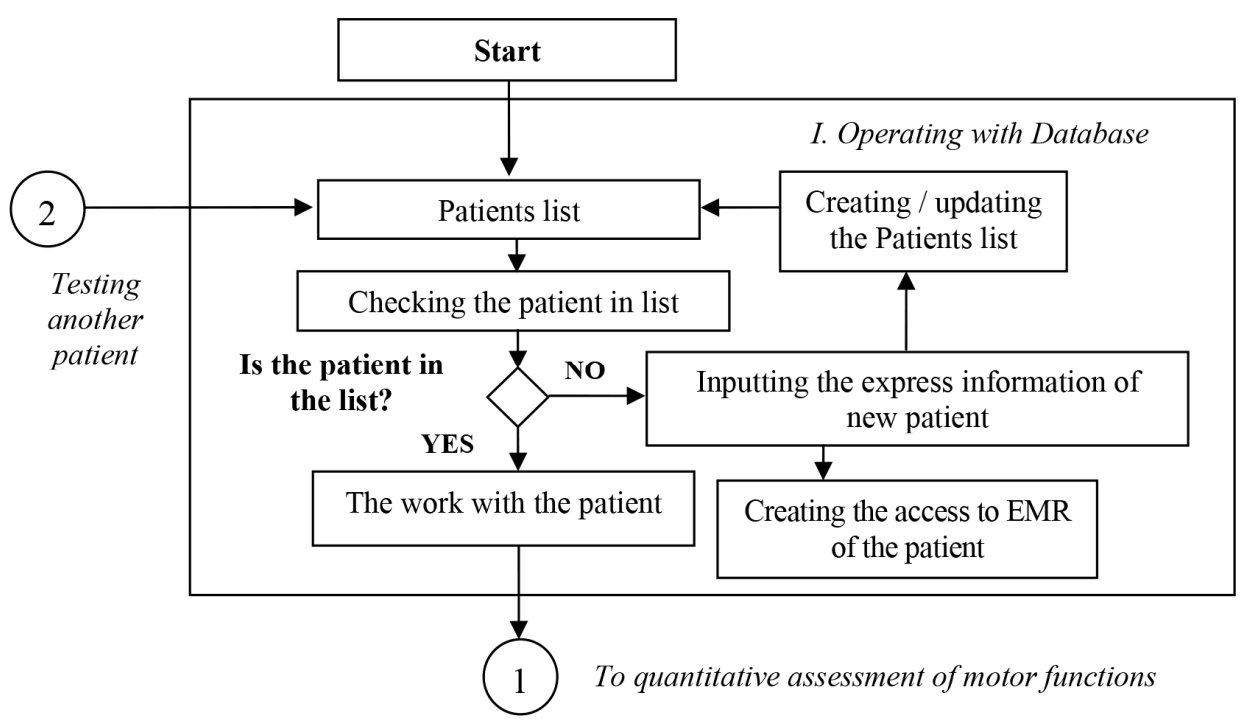

Fig. 3. Algorithm for motor functions testing by software module "MovementTestStroke 1.1". Identical part for PC and mobile devices — Operating with Database 
If it is necessary, the user may test another object. Otherwise there is a transition to II.2 Presentation of the results of quantitative assessment.

In case of sufficient information for assessing the motor functions restoration effectiveness of selected tested objects, the integrated assessments of motor functions, deficit for these objects of the first test are loaded from component I.2 of Database.

The effectiveness is determined by comparing the integrated assessments for current and first tests, and isn't determined in case of data absence of the first test for selected tested object.

The results of motor functions of current test and motor restoration effectiveness (in case of its presence) are stored in component $I .2$ of Database and are displayed by program on the GUI.

If there is enough information to view the dynamics of test results, the data of distributed expert and integrated assessments of the deficit of motor functions for current and previous tests are downloaded from personal EMR to display them on the GUI.

At the end of work with current patient the user can test another patient or finish the program.

Limitation of screen size of mobile devices causes a difference in the relationship between the user and the information units, their components through the GUI, and the redistribution of functions of the Assessment unit components (Fig. 2). This difference is reflected in the algorithm for mobile devices (Fig. 5) and takes place when user selects tested object.

In the structure of mobile platforms (Fig. 5) the verbal characteristics for each criterion are displayed on the GUI according to tested object. The user selects a verbal characteristic that corresponds to the motor function deficit according to selected criterion. According to this characteristic, a quantitative indicator of motor functions deficit in points is automatically determined and displayed on the GUI.

If it is necessary, the user may test another object. Otherwise for selected tested objects the integrated assessments of deficit are calculated and the paresis degrees are determined.

Then there is a transition to II.2 Presentation of the results of quantitative assessment, and the testing algorithm continues as for personal computer (Fig. 4, Fig. 5).

\section{ACTIVITY DIAGRAMS OF SOFTWARE MODULES FOR PERSONAL COMPUTER AND MOBILE DEVICES}

UML-activity diagrams of specialized software modules "MovementTestStroke 1.1 (PC)" (Fig. 7) and "MovementTestStroke 1.1 (MD)" (Fig. 8) describe sequential and parallel calculations by these modules according to the testing algorithms (Fig. 4, Fig. 5). Operating with Database is the identical part for UMLactivity diagrams both for PC and mobile platforms (Fig. 6).

The diagrams show the nodes of decisions and associations ("diamonds"), which are an analog to the logical function "OR", synchronization lines, which are an analog to the logical function "AND", initial and final activity nodes (appropriately "Start program" and "End program" (Fig. 5-Fig. 7) according to UML-notation [12, 13].

The software modules are built so that you can return to the previous stage from each subsequent stage. Quantitative indicators of motor functions deficit for each evidence criterion for tested object, as well as an integrated assessment of motor functions 
deficit are obtained in different ways for the structure of personal computer and mobile devices. For the personal computer the integrated assessment of particular tested object is provided immediately after obtaining the quantitative indicators in points for all criteria, but for mobile devices — only after assessment in points of all selected tested objects by all criteria.

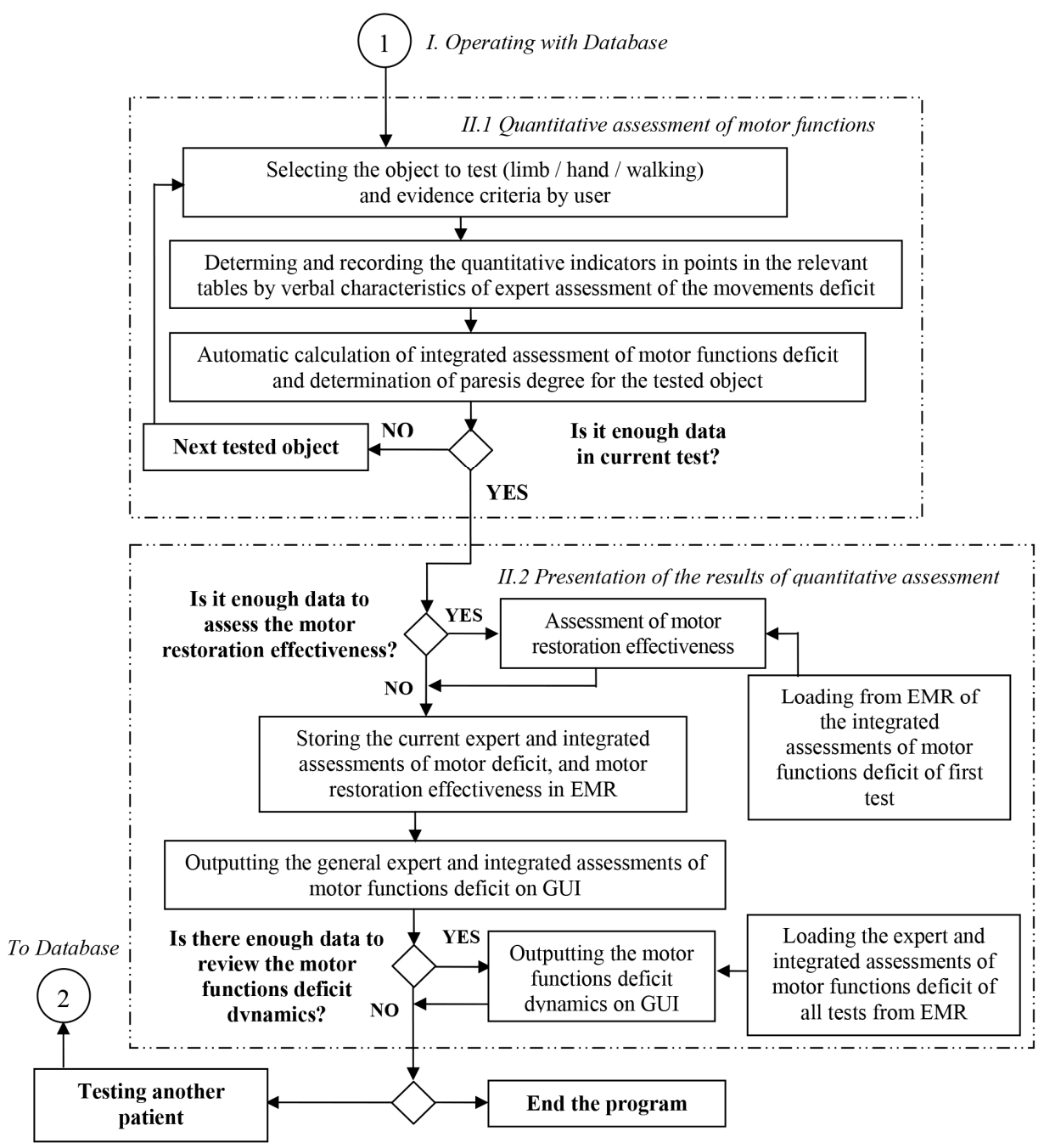

Fig. 4. Algorithm for motor functions testing by software module "MovementTestStroke 1.1". Operating with Information unit of quantitative assessment of motor functions deficit for PC 


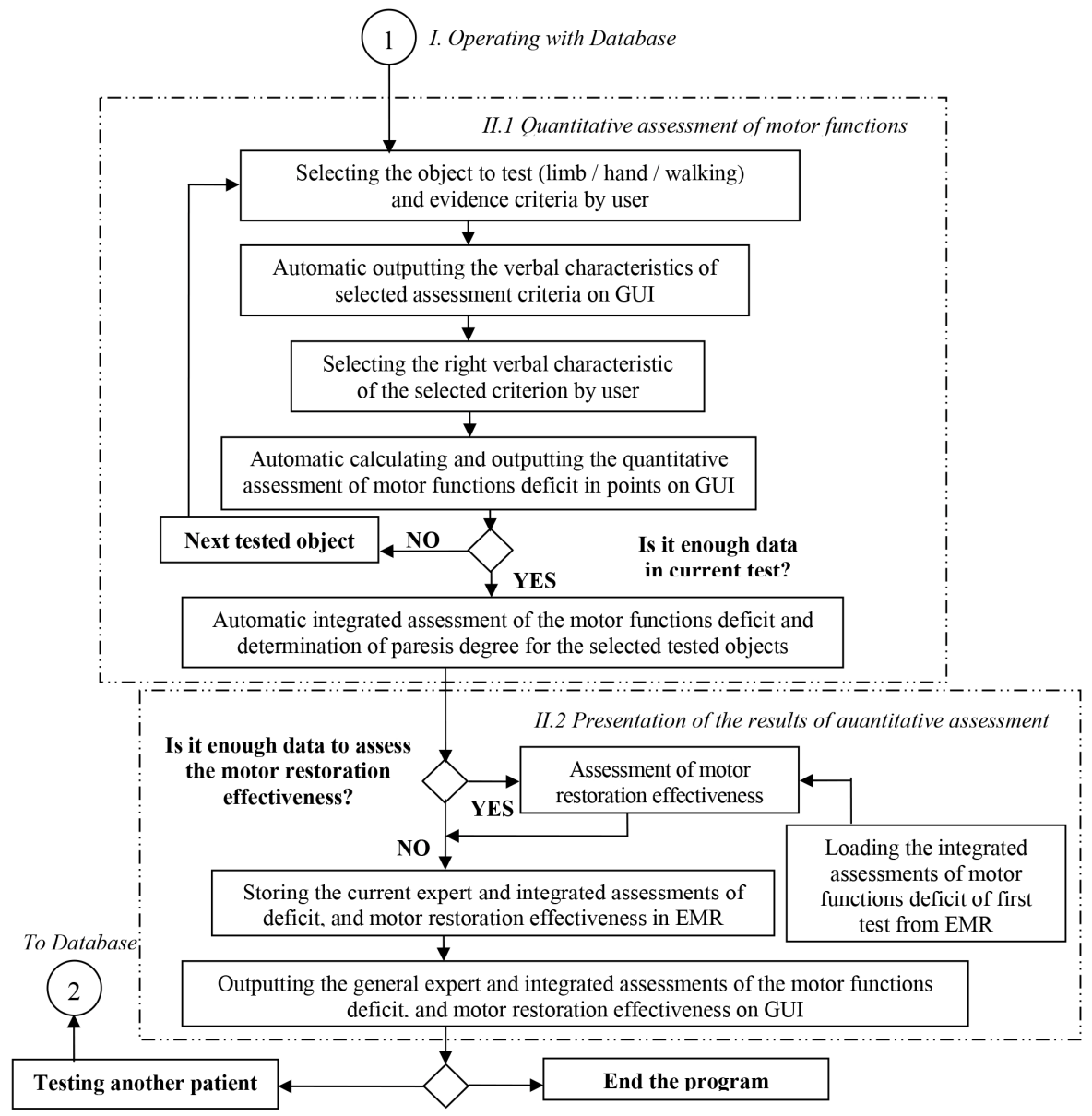

Fig. 5. Algorithm for motor functions testing by software module "MovementTestStroke 1.1". Operating with Information unit of quantitative assessment of motor functions deficit for mobile devices

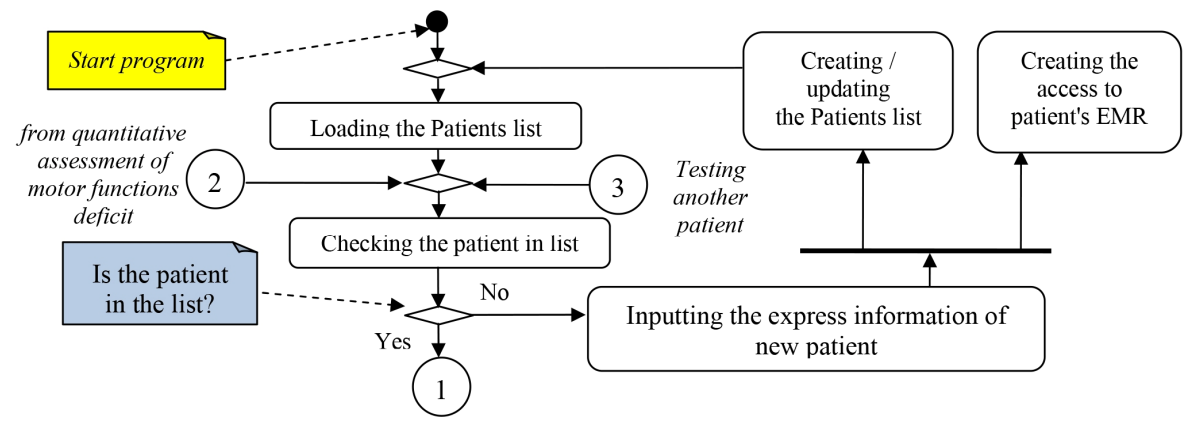

The work with patient

Fig. 6. UML-activity diagram of the software module "MovementTestStroke 1.1". Identical part for PC and mobile devices - Operating with Database 


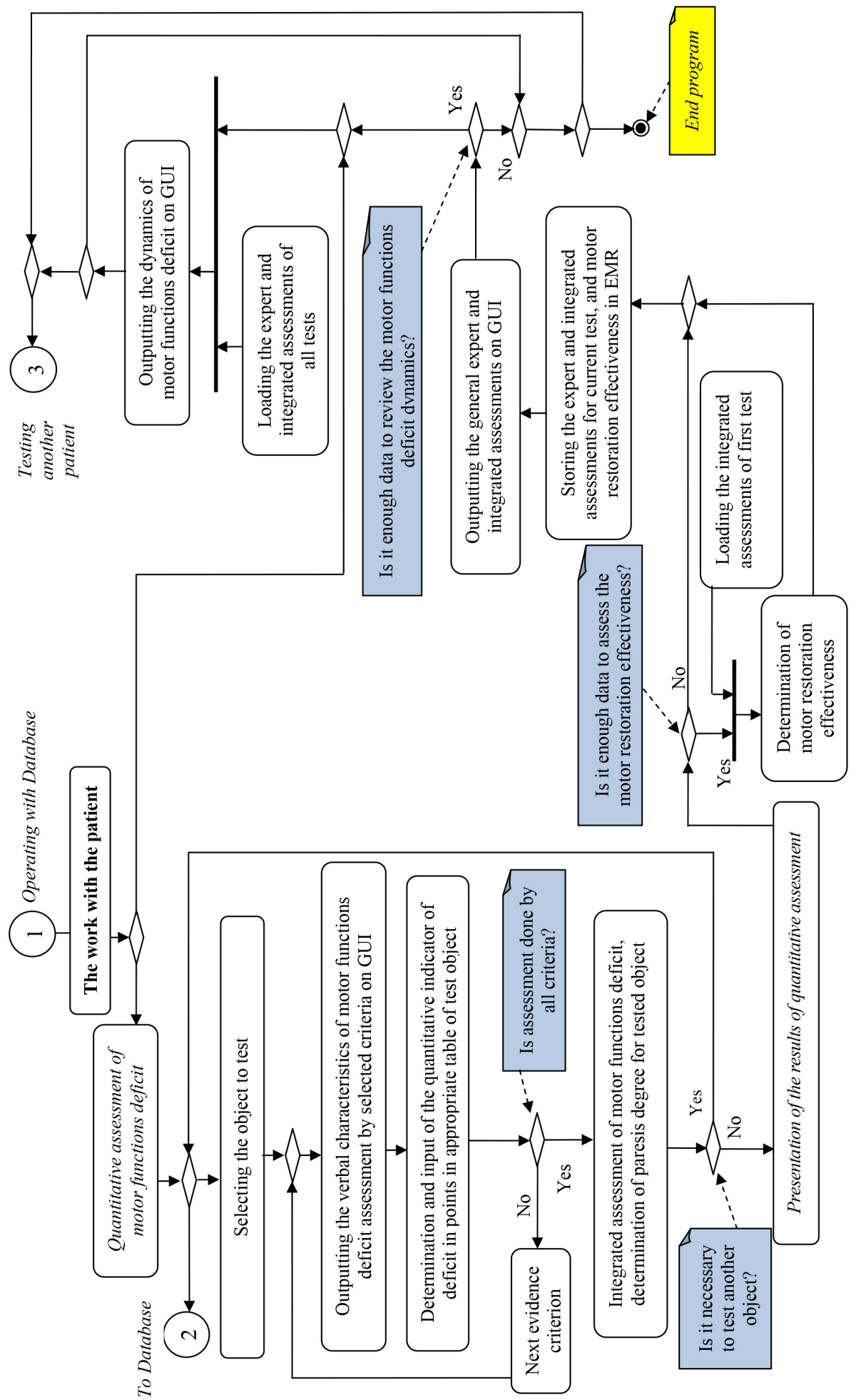

Fig. 7. UML-activity diagram of the software module "MovementTestStroke 1.1 ". Operating with Information unit of quantitative assessment of motor functions deficit for PC 


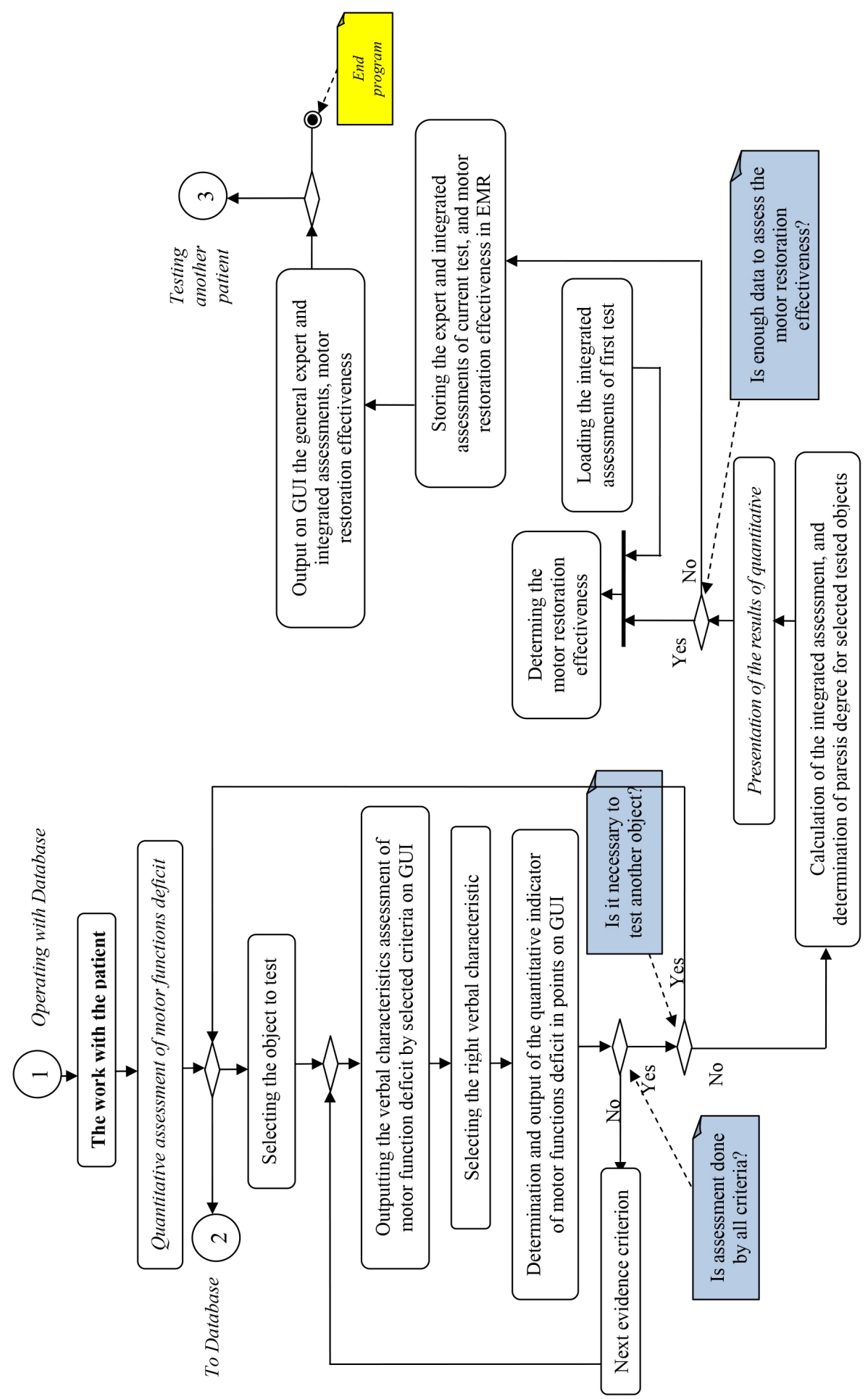

Fig. 8. UML-activity diagram of the software module "MovementTestStroke 1.1". Operating with Information unit of quantitative assessment of motor functions deficit for mobile devices 
Thus, artificial intelligence was used to increase the effectiveness of the diagnostic process of motor functions deficit after stroke. As artificial intelligence tools, a new class of specialized software modules for motor functions diagnostics "MovementTestStroke 1.1 (PC)" for PC-structure, and "MovementTestStroke 1.1 (MD)" for mobile platforms running under Android operation system were developed. Software implementation - Visual Studio 2019, C\# programming language. Structural and functional models of physician - software modules interaction, algorithms for motor functions deficit diagnostics, and UML-activity diagrams of these modules were developed.

\section{CONCLUSIONS}

The advantage of diagnosing is the usage of individual norm. Assessment of motor functions of the affected limbs is performed relative to the patient's own healthy limbs. The same six-step gradation of paresis degree, and generally accepted verbal assessment of effectiveness (no change, slight improvement, improvement, significant improvement) reduce the physician's error.

An expanded range of evidence criteria for assessing the motor functions deficit that includes integrated assessment of limbs at the level of individual joints by two criteria, in addition to the hand - by four criteria, the form of walking, muscle hyperor hypotone, makes it possible to identify the disorders specifics and fulfill comparative analisys of the deficit.

Storing in the Database and displaying on the Interface the results of deficit assessment, deficit dynamics during rehabilitation course in a user-friendly form (tables, graphs) also helps to reduce physician's error in motor functions diagnosing, helps to prevent complications, identify disorders specifics, compare effectiveness of upper and lower limbs, their distal and proximal parts including fine motor skills of the hand, the restoration of which helps to restore oral speech in the case of motor or motor and sensory aphasia.

Mobile AI-technology for motor functions diagnostics can be used not only after a stroke, but also traumatic brain injury, brain tumors, etc. The mobility creates conditions for its mass usage in clinical, outpatient settings, at home, in educational programs.

The implementation of artificial intelligence tools for diagnostics of motor disorders helps to increase the effectiveness of diagnostics and, as a consequence, rehabilitation services for patients.

\section{REFERENCES}

1. Norrving Bo. Action Plan for Stroke in Europe 2018-2030. European Stroke Journal. 2018. Vol. 3(4). pp. 309-336.

2. Vovk M.I., Kutsiak O.A., Lauta A.D., Ovcharenko M.A. Information Assistance of Researches on the Dynamics of Movement Restoration After the Stroke. Cybernetics and Computer Engineering. 2017, № 3 (189), pp. 61-78. (in Ukrainian)

3. Gritsenko V.I., Vovk M.I. Trenar - Innovative Technology of Restoration of Movements. Science and Business - the basis of economic development: materials of the International Scientific and Practical Forum. Ukraine, Dnipropetrovsk, 2012, pp. 204-206. (in Russian)

4. Varun H Buch, Irfan Ahmed, Mahiben Maruthappu. Artificial intelligence in medicine: current trends and future possibilities. Br J Gen Pract. 2018. № 68(668). pp. 143-144.

5. Bernard Marr. The 9 Biggest Technology Trends That Will Transform Medicine And Healthcare In 2020. URL: https://www.forbes.com/sites/bernardmarr/2019/11/01/the-9biggest-technology-trends-that-will-transform-medicine-and-healthcare-in-2020/?sh= 6db7334072cd (Last accessed: 1.04.2021) 
6. Ahuja A.S. The impact of artificial intelligence in medicine on the future role of the physician. PeerJ. 2019. URL: http://doi.org/10.7717/peerj.7702 (Last accessed: 1.04.2021)

7. Artificial intelligence in medicine: the main trends in the world. URL:https://medaboutme.ru/zdorove/publikacii/stati/sovety_vracha/iskusstvennyy_intell ekt_v_meditsine_glavnye_trendy_v_mire/ (Last accessed: 1.04.2021) (in Russian).

8. Vovk M.I., Kutsyak O.A. Software module for personal diagnostics of motor functions after stroke. Cybernetics and Computer Engineering. 2019, № 4 (198), pp. 62-77.

9. Belova A., Shchepetova O. Scales, tests and questionnaires in medical rehabilitation. Moscow: Antidor, 2002. 440 p. (in Russian)

10. Smychek V., Ponomareva E. Craniocerebral trauma (clinic, treatment, examination, rehabilitation). Minsk: Research Institute of ME and R, 2010. 430 p. (in Russian)

11. Certificate of registration the copyright "Computer program «Diagnostics of deficit of general limb movement, fine motor skills of the hand, walking form by the technique for quantitative assessment of movements deficit in patients after stroke "MovementTestStroke 1.0 (PC)"»" / M.I. Vovk, O.A. Kutsiak (Ukraine); No. 98161; published dated 16.06.2020 (in Ukrainian).

12. Booch G., Rumbaugh J., Jacobson I. The Unified Modeling Language User Guide. Boston: Addison-Wesley Professional, 1998. 391 p.

13. Fowler M. UML Distilled: A Brief Guide to the Standard Object Modeling Language. Boston: Addison-Wesley Professional, 2004. 175 p.

\section{ЛІТЕРАТУРА}

Received 01.04.2021

1. Norrving Bo. Action Plan for Stroke in Europe 2018-2030. European Stroke Journal. 2018. Vol. 3(4). pp. 309-336.

2. Вовк М.І., Куцяк О.А., Лаута А.Д., Овчаренко М.А. Інформаційний супровід досліджень динаміки відновлення рухів після інсульту. Кибернетика и вычислительная техника. 2017. №3 (189). С. 61-78.

3. Гриценко В.И., Вовк М.И. Тренар - инновационная технология восстановления движений. Наука $i$ бізнес - основа розвитку економіки: матеріали Міжнародного науково-практичного форуму. Дніпропетровськ, 2012. С. 204-206.

4. Varun H Buch, Irfan Ahmed, Mahiben Maruthappu. Artificial intelligence in medicine: current trends and future possibilities. Br J Gen Pract. 2018. № 68(668). pp. 143-144.

5. Bernard Marr. The 9 Biggest Technology Trends That Will Transform Medicine And Healthcare In 2020. URL: https://www.forbes.com/sites/bernardmarr/2019/11/01/the-9biggest-technology-trends-that-will-transform-medicine-and-healthcare-in2020/?sh=6db7334072cd (Дата звернення: 1.04.2021)

6. Ahuja A.S. The impact of artificial intelligence in medicine on the future role of the physician. PeerJ. 2019. URL: http://doi.org/10.7717/peerj.7702 (Дата звернення: 1.04.2021)

7. Искусственный интеллект в медицине: главные тренды в мире. URL: https://medaboutme.ru/zdorove/publikacii/stati/sovety_vracha/iskusstvennyy_intellekt_v meditsine_glavnye_trendy_v_mire/ (Дата звернення: 1.04.2021).

8. Vovk M.I., Kutsyak O.A. Software module for personal diagnostics of motor functions after stroke. Cybernetics and Computer Engineering. 2019. № 4 (198). pp. 62-77.

9. Белова А., Щепетова О. Шкалы, тесты и опросники в медицинской реабилитации. М.: Антидор, 2002. $440 \mathrm{c}$.

10. Смычек В., Пономарева Е. Черепно-мозговая травма (клиника, лечение, экспертиза, реабилитация). Мн.: НИИ МЭ и Р, 2010. 430 с.

11. Свідоцтво про реєстрацію авторського права на твір. «Комп’ютерна програма «Діагностика дефіциту загальних рухів кінцівок, тонкої моторики кисті, форми ходи за методикою кількісного оцінювання дефіциту рухових функцій у пацієнтів після інсульту “MovementTestStroke 1.0 (РC)”» / М.І. Вовк, О.А. Куцяк (Україна); № 98161 опубл. від 16.06.2020. 
12. Booch G., Rumbaugh J., Jacobson I. The Unified Modeling Language User Guide. Boston: Addison-Wesley Professional, 1998. $391 \mathrm{p}$.

13. Fowler M. UML Distilled: A Brief Guide to the Standard Object Modeling Language. Boston: Addison-Wesley Professional, 2004. 175 p.

Отримано 01.04.2021

Вовк M.I., канд. біол. наук, старш. наук. співроб.,

зав. відд. біоелектричного керування та медичної кібернетики

ORCID: 0000-0003-4584-9553

e-mail: vovk@irtc.org.ua; imvovk3940@gmail.com

Куияк O.A., канд. техн. наук,

старш. наук. співроб. відд. біоелектричного керування та медичної кібернетики

ORCID: 0000-0003-2277-7411

e-mail: spirotech85@ukr.net

Міжнародний науково-навчальний центр інформаційних технологій

і систем НАН України та МОН України,

пр. Акад. Глушкова 40, м. Київ, 03187, Україна

\section{АІ-ТЕХНОЛОГІЯ ДІАГНОСТИКИ РУХОВИХ ФУНКЦІЙ ПІСЛЯ ІНСУЛЬТУ}

Вступ. Діагностика рухових функцій відіграє важливу роль у відновному лікуванні рухів після інсульту. Синтез ефективних технологій з персоналізованого оцінювання порушень рухових функцій на різних етапах реабілітації $є$ актуальним науковоприкладним завданням.

Мета дослідження - розробити інформаційну технологію діагностики дефіциту рухових функцій після інсульту, яка для підвищення ефективності діагностичного процесу використовує елементи штучного інтелекту.

Результати. Розроблено теоретичні і практичні засади синтезу AI-технології діагностики дефіциту рухових функцій після інсульту та оцінювання ефективності їхного відновлення внаслідок реабілітаційних заходів. Для інформаційної допомоги лікарю у діагностичному процесі використовуються елементи штучного інтелекту новий клас засобів мобільної цифрової медицини, спеціалізовані програмні модулі діагностування рухових функцій «MovementTestStroke 1.1 (РC)» для структури персонального комп'ютера і «MovementTestStroke 1.1 (MD)» для мобільних платформ під керуванням операційної системи Android. Надано структурно-функційні моделі взаємодії лікаря 3 програмними модулями, алгоритми діагностики дефіциту рухових функцій, UML-діаграми діяльності зазначених модулів. Програмна реалізація середовище Visual Studio 2019, мова програмування - C\#.

Функційні особливості технології: розширена гама доказових критеріїв персоналізованого кількісного оцінювання дефіциту рухів кінцівок, збереження у базі даних і відображення на інтерфейсі результатів оцінювання дефіциту, а також динаміки дефіциту впродовж курсу реабілітації у зручному для лікаря вигляді (таблиці, графіки), що запроваджено у технологію, уможливлюють зменшення помилки лікаря, запобігання розвитку ускладнень, виявлення специфіки порушень, порівняння ефективності реабілітації верхніх-нижніх кінцівок, їхніх дистальних і проксимальних відділів, у тому числі тонкої моторики кисті, відновлення якої сприяє відновленню мовлення у разі моторної або моторно-сенсорної афазії.

Висновки. Використання засобів штучного інтелекту для діагностики дефіциту рухових функцій сприятиме підвищенню ефективності діагностичних i, як наслідок, реабілітаційних послуг пацієнтам після інсульту.

Ключові слова: діагностика, рухові функиії, інсульт, персональна кількісна оцінка, критерії, технологія, итучний інтелект, програмний модуль, структурно-функиійна модель, алгоритм, діаграма діяльності. 